DOI: https://doi.org/10.30525/978-9934-26-081-0-2

\title{
INTERNATIONAL MILITARY COOPERATION IN THE NATIONAL SECURITY SYSTEM OF THE COUNTRY
}

\author{
Kaspars Kikste \\ Postgraduate student \\ ISMA University of Applied Sciences \\ Riga, Republic of Latvia
}

The prerequisites for the development of international military cooperation of countries may be the following circumstances: historical (historically established relations between countries), political (the presence of common political goals or threats), geographical (proximity to location), economic (the presence of stable long-term trade, financial and other aspects of cooperation) etc. Each of the above are important prerequisites for the development and deepening of cooperation in the military sphere. But one of the most important prerequisites is the 
presence of an external threat to the country's security. In the modern world, the number of such threats is growing rapidly. Along with such as religious extremism, terrorism, piracy, unfortunately, the threats associated with the predatory ambitions of individual countries, their aspirations to seize territories and the buildup of weapons of mass destruction do not disappear.

The economic potential of countries is very different, as a consequence of the different are their ability to withstand external threats. That is why the development of international cooperation with partner countries is the most important condition for strengthening its national security. The most developed form of international military cooperation is the creation of international military blocs.

The largest world organization is the United Nations, which for many years has been making efforts to maintain international peace and stability, to resolve international conflicts. By decision of the UN Security Council, in accordance with its charter, peacekeeping missions can be sent to different parts of the world in order to stop conflicts.

The most successful military alliance is considered to be NATO (North Atlantic Treaty Organization) - a military-political alliance of the states of North America and Europe, which have united their efforts to create collective defense, preserve peace and security. After the Russian aggression in 2014, NATO's activities take on particular importance for all countries in the region. NATO's priorities in this context are two areas - the Baltic region and the Black Sea region. The Baltic region is represented by NATO member states and two close partners - Sweden and Finland. The Black Sea region has three NATO members (Turkey, Romania and Bulgaria) and 3 partners (Ukraine, Georgia and Moldova).

A country's participation in a military bloc presupposes certain obligations, both in terms of standards of military activity and economic indicators. In NATO countries, the indicator is adopted as a guideline $2 \%$ of GDP for military needs. However, in 2017, only four countries exceeded this indicator: the USA (3.57\%), Greece (2.36\%), the United Kingdom (2.12\%), Estonia (2.08\%). On average, military spending in NATO countries amounted to $2.42 \%$ of GDP this year. In absolute terms, the leaders in 2017 were: the United States (\$ 686 billion), the United 
Kingdom ( $\$ 55$ billion), France ( $\$ 46$ billion), Germany ( $\$ 45.5$ billion) [1]. In 2020, the level of 2 percent of GDP was already surpassed by 11 countries: the USA $(3.73 \%)$, Greece $(2.68 \%)$, Estonia $(2.33 \%)$, the United Kingdom (2.32\%), Poland (2, 31\%), Latvia (2.27\%), Lithuania $(2.13 \%)$, Romania $(2.07 \%)$, France $(2.04 \%)$, Norway $(2.0 \%)$, Slovakia $(2.0 \%)$. The average indicator has also grown $-2.77 \%$ of GDP [2].

Thus, the aggravation of the military-political situation in the world and in the region has as its consequence an increase in countries' expenditures for military purposes. An important task is to use the potential of international cooperation to reduce tensions, avoid military conflicts and achieve global stability.

\section{References:}

1. Defense expenditures of NATO Countries (2010-2017) Spending by Country (2018). URL: https://www.nato.int/nato_static_fl2014/assets/pdf/pdf_2018_03/2018 0315_180315-pr2018-16-en.pdf.

2. Defense expenditures of NATO Countries (2013-2020) Spending by Country (2021). URL: https://www.nato.int/nato_static_fl2014/assets/pdf/2021/3/pdf/210316pr-2020-30-en.pdf. 